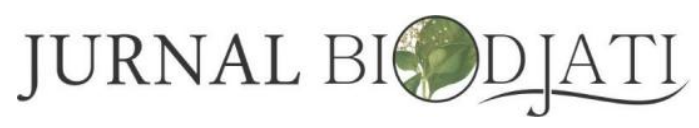

http://journal.uinsgd.ac.id/index.php/biodjati

\title{
PEMANFAATAN ANGGREK SPESIES KALIMANTAN TENGAH BERBASIS KEARIFAN LOKAL YANG BERPOTENSI SEBAGAI BAHAN OBAT HERBAL
}

\author{
Tri Suwarni Wahyudiningsih ${ }^{1}$, Yanetri Asi Nion², Pahawang $^{3}$ \\ ${ }^{1,3}$ Program Studi Kehutanan, Fakultas Pertanian Universitas Palangka Raya \\ ${ }^{2}$ Program Studi Agroteknologi, Jurusan Budidaya Pertanian, Fakultas Pertanian Universitas Palangkaraya
}

\section{Diterima 05 September Disetujui 24 November 2017 \\ Publish 30 November 2017}

trisuwarni@untidar.ac.id email :

tri.s.wbasuki@gmail.com, yanetriasinion@agr.upr.ac.id, forestyunpar@gmal.com

e-ISSN : 2541-4208

p-ISSN : 2548-1606
Abstrak. Pemanfaatan anggrek spesies dari Kalimantan Tengah yang berpotensi sebagai bahan obat herbal berbasis kearifan lokal perlu dikaji. Penelitian dilakukan mulai bulan Oktober hingga Desember 2016. Tempat penelitian: koleksi anggrek spesies Kalimantan Tengah di Jl.Temanggung Tilung XIII Palangka Raya. Pemanfaatan anggrek spesies berdasar kearifan lokal berasal dari hasil wawancara pemilik kebun yang didukung dengan data hasil studi literatur. Spesies anggrek dari Kalimantan Tengah yang bermanfaat sebagai bahan obat herbal adalah batang dan daun anggrek tewu tadung/anggrek tebu (Grammatophylum speciosum) sebagai bahan obat kista dan uwei menyame (Bromheadia finlaysoniana (Lind.) Miq.) sebagai salah satu komponen obat sakit pinggang. Beberapa anggrek spesies yang berpotensi sebagai bahan obat herbal dan fitoterapi berdasar studi literatur antara lain: rhizome anggrek bambu (Arundina graminifolia (D. Don) Hochr) mengandung senyawa Arundinan mempunyai aktivitas anti bakteri. Daun Phalaenopsis manii mengandung phalaenopsine. Seluruh bagian tumbuhan Eria bambusifolia Lindl. Kimar digunakan untuk mengatasi keasaman lambung yang berlebihan dan gangguan sakit perut. Anggrek Coelogyne cristata mengandung Coeloginanthrin, Coeloginanthridin, dan Combretastatin C-1. Daun Dendrobium crumenatum Sw. (anggrek merpati) dapat digunakan untuk tapal pada bisul dan jerawat.

Kata kunci : Anggrek Spesies, Herbal, Kearifan Lokal, Tewu Tadung, Uwei Menyame

Abstract. The use of orchids species in Central Kalimantan potentially as a medicinal herbs based on local knowledge need to assessed. Implementation research started in October to December 2016. The samples was a collection of orchids species from Central Kalimantan on Temanggung Tilung XII street, Palangka Raya. The application of orchids as medicinal herbs based on local knowledge derived from interviews of plantation owners and literature study. Orchid species in Central Kalimantan which utilized local communities as a medicinal herbs are stems and the leaves of an orchid tewu tadung / orchids cane (Grammatophylum speciosum) which apply as medicine for cyst and Uwei Menyame (Bromheadia finlaysoniana (Lind.) Miq.) as one of the components of the medicine for lumbago. Orchids species which has potency to be used as a medicinal herbs and fitoterapi based literature 


\section{JURNAL BIODJATI}

http://journal.uinsgd.ac.id/index.php/biodjati

study were rhizoma of orchids bamboo (Arundina graminifolia (D. Don) Hochr) which containing arundinan that have antibacteria property, leaves of Phalaenopsis manii which containing phalaenopsine, all parts of body part of Eria bambusifolia lindl. Kimar which can be use to address acidity of the stomach excessive and colic disorders, Coelogyne cristata which containing coeloginanthrin, coeloginanthridin, and combretastatin c-1 and leaves of Dendrobium crumenatum sw. or orchids pigeon which can be use as a poultice on ulcer and acnes.

Key words : Orchids Species, Herbs, Local Wisdom, Tewu Tadung, Uwei Menyame

\section{Cara Sitasi}

Wahyudiningsih, T. S., Nion, Y. A. \& Pahawang. (2017). Pemanfaatan Anggrek Spesies Kalimantan Tengah Berbasis Kearifan Lokal yang Berpotensi sebagai Bahan Obat Herbal. Jurnal Biodjati, 2 (2), Hal 149-158.

\section{PENDAHULUAN}

Orchidaceae merupakan famili tumbuhan berbunga yang terbesar dan paling berevolusi. Famili ini terdiri atas 25.000 hingga 35.000 spesies dari 750 sampai 850 genera (Dressler, 1993; Singh et al., 2001; Hossain, 2009). Orchidaceae ditemukan di semua daerah dari Antartika hingga gurun yang panas, tetapi keragaman paling besar terdapat di daerah tropis dan subtropis. Kontribusi Orchidaceae Indonesia dalam khasanah anggrek dunia cukup besar dimana 6.000 jenis dapat ditemukan di hutan Indonesia. Chan et al. (1994) memperkirakan bahwa 2.500-3.000 jenis anggrek terdapat di Kalimantan atau $75 \%$ dari tumbuhan anggrek Malesian dan sekitar 30-40\% endemik Kalimantan.

Famili Orchidaceae bernilai ekonomi yaitu sebagai tanaman hias berestetika tinggi, termasuk tumbuhan inti untuk bahan obat herbal dan mengandung glikosida penting serta digunakan untuk fitoterapi karena keindahan bunga dan aromanya memberi efek relaksasi. Fitokimia pada Orchidaceae secara umum dikatagorikan sebagai alkaloid, flavonoid, karotenoid, anthosianin, dan sterol.
Pemanfaatan famili orchidaceae sebagai obat herbal di Cina, India, Pakistan sudah berlangsung cukup lama, namun demikian penelitian farmakologi dan toksikologi famili tersebut pada tubuh manusia belum diimplementasikan secara klinik.

Kajian mengenai pemanfaatan anggrek spesies di Indonesia untuk obat herbal belum banyak diteliti. Pulau Kalimantan memiliki 2.500-3.000 jenis anggrek, dengan demikian perlu dimulai penelitian mengenai pemanfaatan anggrek spesies sebagai bahan obat herbal berbasis kearifan lokal di Kalimantan Tengah. Tujuan penelitian ini untuk menginventarisasi anggrek spesies dari Kalimantan Tengah berbasis kearifan masyarakat lokal dan kajian ilmiah dari literatur untuk bahan obat herbal.

\section{BAHAN DAN METODE}

\section{Waktu dan Tempat Penelitian}

Penelitian dilakukan bulan OktoberDesember 2016. Anggrek yang diamati adalah koleksi dan budidaya anggrek spesies Kalimantan Tengah milik Setya Murniasih di J1. Temanggung Tilung XIII. Berdasar informasi pemilik anggrek spesies diperoleh 


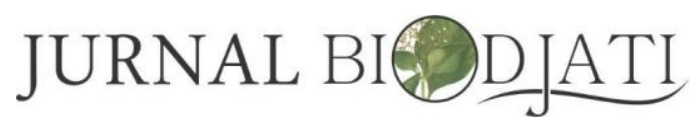

http://journal.uinsgd.ac.id/index.php/biodjati

dari daerah Tewah, Buntok, dan Palangka Raya, Kalimantan Tengah.

\section{Bahan dan Alat}

Bahan yang digunakan untuk koleksi anggrek yaitu pot, media sabut kelapa, dan screen. Alat yang dipergunakan adalah kamera untuk dokumentasi.

\section{Cara Kerja}

Cara kerja dalam penelitian adalah sebagai berikut:

1. Koleksi anggrek spesies dikelompokkan berdasar pemanfaatan untuk obat tradisional berdasar kearifan lokal dari wawancara kepada pemilik kebun koleksi anggrek spesies dan studi literatur.

2. Data yang dihasilkan dari identifikasi dan karakterisasi didokumentasikan dalam file khusus dalam komputer untuk memudahkan pengamanan dan pengaksesan kembali data yang disimpan. Setiap jenis anggrek yang bermanfaat untuk obat juga didokumentasikan dalam bentuk foto.

\section{HASIL DAN PEMBAHASAN}

Koleksi anggrek spesies Kalimantan Tengah yang dimiliki pekebun sebanyak 300 spesies. Tanaman anggrek spesies berasal dari hutan daerah Tewah, Muara Teweh dan Palangka Raya. Berdasarkan hasil wawancara dengan pemilik kebun, spesies anggrek yang sering dicari dan dimanfaatkan masyarakat lokal untuk bahan obat herbal adalah Anggrek Tewu Tadung atau Anggrek Tebu (Grammatophylum speciosum) dan Uwei Menyame (Bromheadia finlaysoniana).

Nama lokal Tewu Tadung, tewu berarti tebu dan tadung berarti ular tadung. Hal ini disebabkan karena batang anggrek tebu mempunyai bekas ruas daun menyerupai ular tadung (Gambar 1b). Deskripsi : Batang berbentuk bundar tertutup daun, tinggi batang 3-7 m; Daun berbentuk jorong, tersusun rapat, berdaging, panjang 20-30 cm, lebar 7- $12 \mathrm{~cm}$ (Gambar 1a); Bunga berbentuk pita, ujung runcing, panjang 50-100 cm, lebar $3 \mathrm{~cm}$, lama mekar 5 hari, musim berbunga: Juni-Maret, daun kelopak berbentuk lanset, melancip, daun mahkota berbentuk bundar telur, panjang 5,5 cm dan lebar: 2,5 cm; Ekologi: anggrek Tewu tadung tumbuh pada tempat terbuka pada ketinggian 50-550 m dpl.

Bagian organ yang dimanfaatkan oleh masyarakat lokal adalah batang dan daun untuk mengobati mioma. Cara penggunaan tanaman ini terlebih dahulu batang dan daun dicuci hingga bersih, kemudian direbus dengan menggunakan air $400 \mathrm{ml}$ selama 15 menit. Air rebusan setelah dingin disaring dan dapat diminum dua kali sehari.
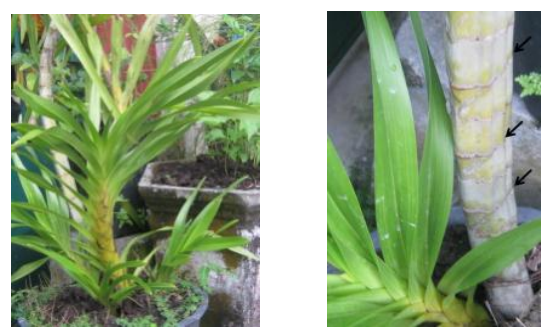

Gambar 1. Anggrek Tewu Tadung/Anggrek Tebu (Grammatophylum speciosum). Keterangan: a). Tumbuhan secara keseluruhan, b). Batang seperti tebu dengan bekas daun menempel (tanda panah) seperti ular tadung

Anggrek Bromheadia finlaysoniana (Lind.) Miq. sinonim dengan Grammatophyllum finlaysonianum Lindl. mempunyai nama lokal Uwei Menyame (Gambar 2). Bentuk batang bulat, monopodial, permukaan batang licin (Gambar 2b). Tipe daun tunggal berseling, bentuk daun memanjang, ujung daun berlekuk, pangkal daun runcing, tepi daun rata, permukaan daun licin, daun muda berwarna hijau muda daun 


\section{JURNAL BIODJATI}

http://journal.uinsgd.ac.id/index.php/biodjati

tua berwarna hijau tua, pertulangan daun sejajar (Gambar 2a dan 2c).

Bromheadia finlaysoniana merupakan anggrek terestrial, tumbuh di lahan basah, biasanya dekat sungai, tumbuh pada ketinggian 0-200 m dpl. Tinggi tumbuhan 11,5 m dengan daun kaku, panjang 100-150 $\mathrm{mm}$, lebar 20-30 mm. Pada saat pengamatan anggrek ini belum berbunga. Anggrek ini ditemukan di daerah Buntok Kalimantan Tengah. Tumbuhan Uwei Menyame berkhasiat untuk mengobati sakit pinggang, tetapi dicampur dengan tumbuhan Saluang Belum dan tumbuhan Pasak Bumi.

Bagian organ yang dimanfaatkan sebagai obat adalah akar (Gambar 2d). Cara pemanfaatan: akar uwei menyame, akar saluang belum, dan akar pasak bumi dicuci sampai bersih, dipotong-potong kemudian dicampur dan dimasukkan dalam botol atau gelas, ini dingin dituangi air panas, didiamkan hingga dingin. Air rendaman diminum dua kali sehari, sampai penyakit sembuh (Ariati, 2015).
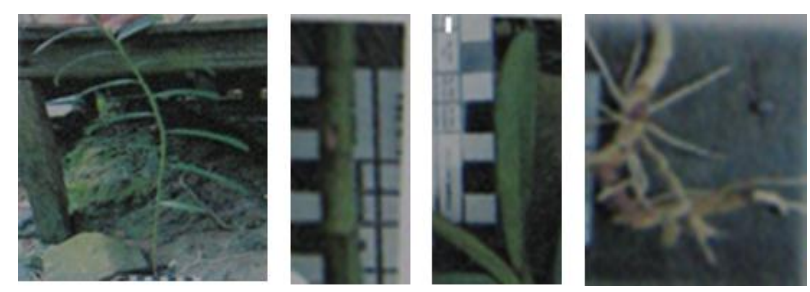

Gambar 2. Tanaman Uwei Menyame (Bromheadia finlaysoniana (Lind.) Miq.). Keterangan: a). Tumbuhan secara keseluruhan, b). Batang, c). Daun, d).Rhizoma dan akar

Beberapa anggrek spesies dapat digunakan sebagai bahan obat herbal dan fitoterapi berdasar studi literatur, tetapi belum dimanfaatkan masyarakat lokal. Jenis-jenis tersebut antara lain: Arundina graminifolia (D. Don) Hochr. (Gambar 3), Dendrobium crumenatum Sw. (Gambar 4), Eria bambusifolia Lindl. Kimar (Gambar 5), Coelogyne cristata (Gambar 6), dan Phalaepsis manii (Gambar 7).

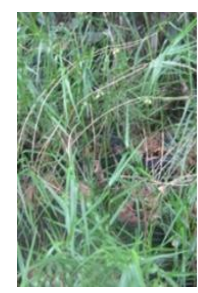

a.

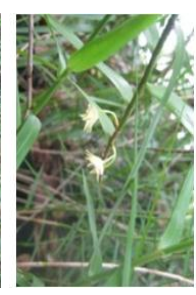

b.

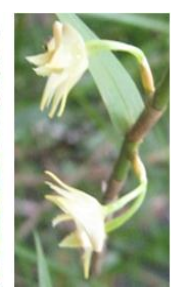

c.

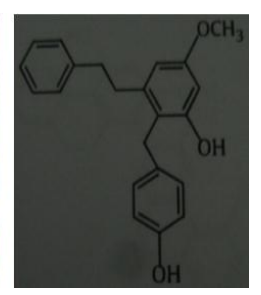

d.
Gambar 3. Tanaman anggrek bambu Arundina graminifolia (D. Don) Hochr. Keterangan: a). tumbuhan secara keseluruhan, b). Daun seperti daun Bambu, c). Bunga berwarna putih kekuningan, d). Struktur kimia Arundinan

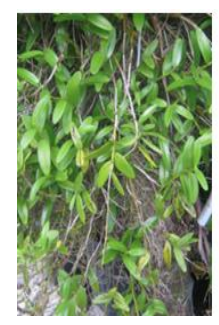

a.

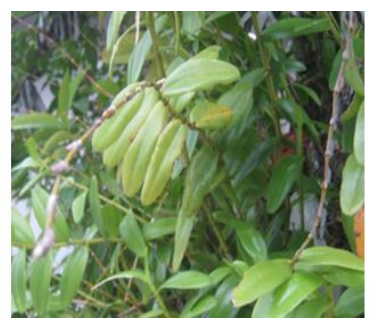

b.

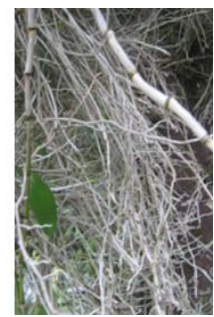

c.
Gambar 4. Morfologi anggrek merpati (Dendrobium crumenatum Sw.). a). tumbuhan secara keseluruhan, b). susunan daun, c). akar berwarna putih.

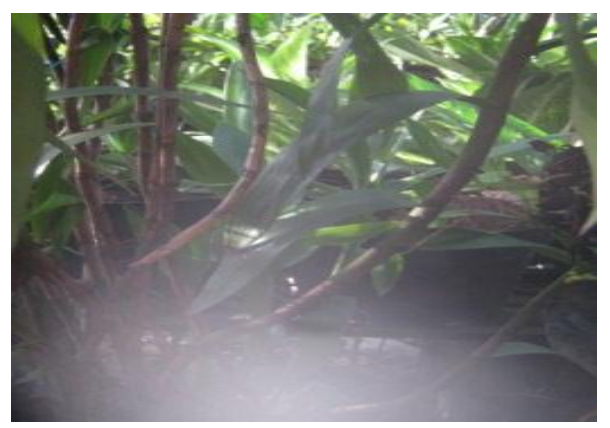

Gambar 5. Morfologi anggrek Eria bambusifolia Lindl. Kimar 


\section{JURNAL BIDDJATI}

http://journal.uinsgd.ac.id/index.php/biodjati

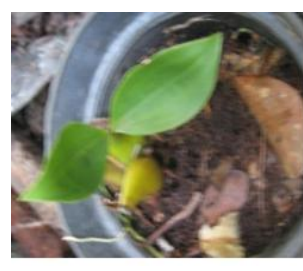

a.

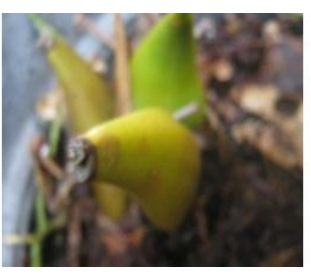

b.

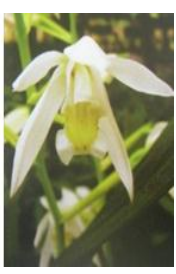

c.
Gambar 6. Anggrek C. cristata. Keterangan: a). Daun, b). bulbus, c). Bunga berwarna putih kekuningan dengan lidah berwarna kuning pucat

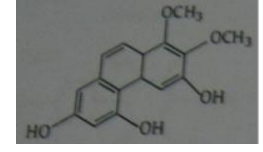

a

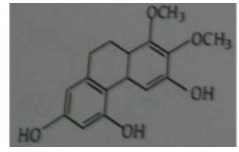

b.

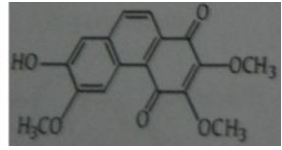

c.
Gambar 7. Struktur kimia yang ditemukan pada anggrek C. cristata a). Coeloginanthrin, b). Coeloginanthridin, c). Combretastatin C-1

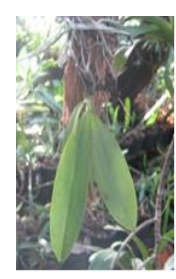

a.

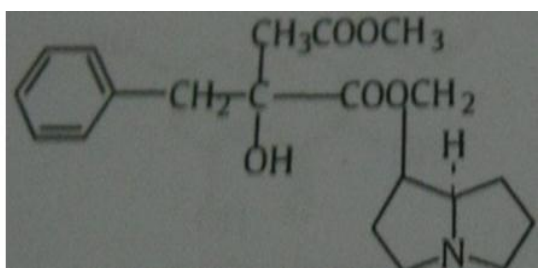

b.
Gambar 8. a). Morfologi anggrek Phaleonopsis manii, b). Struktur kimia phalaenopsine

Famili Orchidaceae seperti tumbuhan lainnya menghasilkan fitokimia, namun baru beberapa yang diteliti mempunyai fungsi biologis, sedang yang lain masih banyak yang belum diketahui. Fitokimia pada Orchidaceae secara umum dikatagorikan sebagai alkaloid, flavonoid, karotenoid, anthosianin, dan sterol. Studi alkaloid dimulai sejak tahun 1892, ketika E. de Wildeman memulai investigasi alkaloid anggrek pada beberapa spesies anggrek di Eropa. Kemudian tahun 1896, E de Droog menganalisis 104 spesies dari 78 genera. Pada akhir tahun 1890, W. Boorsma meneliti alkaloid anggrek di kebun raya Bogor dan mendeteksi beberapa Paphiopedilum javanicum dan Liparis parviflora, dan juga beberapa spesies lain (Hossain, 2011).

Alkaloid yang pertama diisolasi dari anggrek adalah dendrobine pada tahun 1932 dari Cina sebagai obat Cina bernama 'ChinShi-Hu' yang diambil dari Dendrobium nobile (Bhattacharjee, 2006). Spesies Dendrobium diketahui menghasilkan bermacam-macam metabolit sekunder seperti phenanthren, bibenzyl, fluorenone dan sesquiterpene, serta alkaloid dan banyak diantaranya yang secara luas digunakan sebagai obat (Lo et al., 2004). Pada akhir tiga dekade, penelitian pada anggrek Dendrobium diisolasi menghasilkan komponen phenanthrenes antara lain dihydrophenanthrene, ephemeranthoquionone, shihunidine, shihunine, dendrophenol, moscatilin, moscatin, moscatilin, denfigenin, defuscin, amoenumin, moscatilin, crepaditin, rotundatin, cumulatin, dan gigantol (Majumder \& Sen, 1987; Majumder \& Chatterjee, 1989; Majumder \& Pal, 1992; Honda \& Yamaki, 2000; Krohn et al., 2001; Zhang et al., 2007, Li et al., 2008; Hossain, 2011). Pada beberapa genera anggrek lain seperti Eulophia, Cypripedium, Gastrodia, Bletilla, Bulbophyllum, Anoectochilus, Arundina, Eria, Malaxis, Habenaria, Vanda, dan Vanilla kaya fitokimia penting yang berbeda-beda (Hossain, 2011).

Berdasar manfaat fitokimia tersebut di atas, maka koleksi anggrek spesies Kalimantan Tengah sekitar 300 jenis menyimpan potensi sumberdaya genetik baik sebagai tanaman hias maupun tanaman obat. Namun demikian, baru dua jenis anggrek yang dimanfaat masyarakat lokal Kalimantan Tengah yaitu G. speciosum dan B. finlaysoniana (Lind.) Miq. Kedua jenis anggrek tersebut selain bermanfaat sebagai bahan obat herbal juga mempunyai bunga yang 


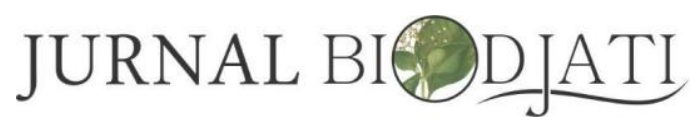

http://journal.uinsgd.ac.id/index.php/biodjati

indah dan unik sehingga banyak dicari oleh kolektor anggrek. Terdapat 4 macam anggrek G. speciosum, yang memiliki perbedaan pada warna bunga dan fenotip, yang ditemukan di Kalimantan Tengah dan tergolong pada jenis anggrek yang dilindungi. Selain bermanfaat sebagai bahan obat herbal, anggrek tebu mempunyai potensi sebagai tanaman hias sehingga perlu dibudidayakan dan merupakan sumberdaya genetik untuk bahan penyilangan bagi pemulia tanaman. Hasil penelitian ini juga belum didukung literatur yang menjelaskan kandungan fitokimia pada anggrek tebu.

Tanaman anggrek B. finlaysoniana (Lind.) Miq. mempunyai bunga yang jarang bercabang, bunga terbuka lebar dan besar, umur bunga yang singkat, berwarna putih dengan warna kuning pada bibir, di dalam lobus samping berwarna putih berurat ungu. Waktu musim berbunga antara bulan Juni Maret. Penyebaran secara luas di daerah tropis Asia dari Myanmar sampai New guinea. Meskipun belum ditemukan literatur yang menjelaskan kandungan fitokimia pada anggrek tersebut, masyarakat lokal menggunakan rebusan akar B. finlaysoniana dikombinasikan dengan akar Saluang Belum dan Pasak Bumi untuk mengobati sakit pinggang. Pemanfaatan jenis anggrek ini yang tidak terkendali sebagai bahan obat herbal maupun tanaman hias tanpa diikuti budidaya menyebabkan spesies ini mengalami ancaman kepunahan. Menurut IUCN, anggrek spesies $B$. finlaysoniana menurut Brummitt (2013) termasuk Redlist of Threatened species.

Bagian organ anggrek $A$. graminifolia yang dimanfaatkan sebagai obat adalah organ rhizoma dan akar. Rhizoma anggrek bambu mempunyai aktivitas sebagai anti bakteri. Rebusan akarnya digunakan untuk mengobati badan yang sakit (Kumar, 2002; Hossain, 2009; Singh \& Duggal, 2009;). Tumbuhan ini mengandung Arundinan (Liu et al., 2005) dengan struktur kimia (Liu et al., 2005; Hossain, 2011) disajikan pada Gambar 2d. Pada Arundina graminifolia ditemukan dua derivat phenanthrene yaitu arundiquinone dan arundigramin (Auberon et.al., 2016).

Jenis anggrek Arundina graminifolia (D. Don) Hochr. atau Bamboo orchidl anggrek bambu disajikan pada Gambar 3. Menurut Sabran et al. (2003) deskripsi anggrek bambu sebagai berikut. Batang berbentuk buluh, tertutup pelepah daun, panjang 0,5-1,5 cm. Daun berbentuk pita, ujung meruncing, tersusun jarang, panjang $20 \mathrm{~cm}$, lebar 0,5-2 $\mathrm{cm}$. Bunga tersusun dalam rangkaian berbentuk tandan yang tumbuh dari ujung batang tegak, panjang 30-40 cm, jumlah bunga tiap tandan 8-15. Lama mekar bunga 4 hari. Musim berbunga bulan Februari. Daun kelopak berbentuk lanset, panjang 5-6 cm, lebar $2-3 \mathrm{~cm}$. Daun mahkota berbentuk lanset, panjang: $5-6 \mathrm{~cm}$, lebar 2-3 cm lebih besar dari daun kelopak. Anggrek ini tumbuh pada tempat terbuka pada ketinggian 30-200 m dpl. Anggrek A. graminifolia penyebarannya cukup luas, biasanya mempunyai banyak keanekaragaman. Hal ini dapat dilihat dari bentuk daun, bunga, dan warna bunga. Keanekaragaman bunga bergantung pada penyesuaian tanaman dengan tempat tumbuhnya.

Sejumlah penelitian menginvestigasi peran kimiawi moscatilin yang berasal dari batang anggrek species Dendrobrium (Chan et al., 1994; Ho \& Chen, 2003; Chen et al., 2008). Spesies ini telah digunakan sebagai obat tradisional sebagai tonik untuk memelihara kesehatan perut, meningkatkan cairan tubuh, dan mengurangi demam. Moscatilin mempunyai aktivitas sebagai anticancer terhadap berbagai jenis cancer, choriocarcinoma, cancer paru-paru, dan cancer 


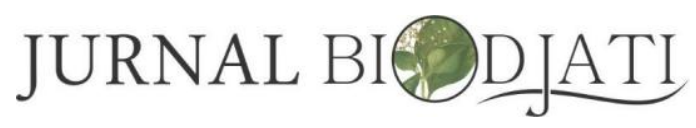

http://journal.uinsgd.ac.id/index.php/biodjati

perut, tetapi tidak efektif untuk cancer hati (Ho \& Chen, 2003).

Berdasar manfaat genus Dendrobium tersebut di atas, maka jumlah anggrek spesies genus Dendrobium sekitar 20 spesies mempunyai potensi juga sebagai bahan obat herbal. Salah satu spesies Dendrobium yang banyak terdapat di Kalimantan Tengah adalah Dendrobium crumenatum Sw. atau anggrek merpati. Anggrek merpati memiliki habitat yang cukup luas mulai dari Indonesia, Singapura, Thailand hingga Philipina. Anggrek ini tumbuh pada cabang-cabang pohon baik di dataran rendah maupun dataran tinggi. Deskripsi D. crumenatum menurut Singh et.al. (2001) sebagai berikut. Bunga memiliki sepala dan petala berwarna putih dengan sedikit kekuningan pada bagian lidah, bau harum semerbak hanya bertahan sehari. Anggrek merpati (Gambar 4a dan 4b) merupakan anggrek monopodial dengan bentuk bulbus membengkak pada bagian bawah dan pipih pada bagian atas. Akar bulat pipih berwarna putih memanjang (Gambar 4c). Bagian organ daun dapat digunakan untuk tapal pada bisul dan jerawat. Anggrek merpati mengandung kardenolin, flavonoid, dan polifenol.

Anggrek spesies Eria bambusifolia Lindl. Kimar. (Gambar 5) yang dimanfaatkan sebagai bahan obat adalah keseluruhan bagian organ tumbuhan. Manfaat tumbuhan ini untuk mengatasi keasaman lambung yang berlebihan dan gangguan sakit perut (Hossain, 2011).

Jenis Coelogyne yang terdapat di Kalimantan Tengah antara lain Coelogyne pandurata (anggrek hitam), $C$. asperata (anggrek madu), C. cristata, $C$. cumingii, $C$. peltates dan $C$. foerstermannii. Jenis Coelogyne yang dimanfaatkan sebagai bahan obat herbal dan ditemukan di Kalimantan Tengah adalah $C$. cristata. Morfologi tanaman C. cristata disajikan pada Gambar 6, terlihat pseudobulbus (Gambar 6b) yang bermanfaat sebagai obat herbal. Menurut Majumder et al. (2001), kandungan fitokimia pada $C$. cristata Lindl adalah Coeloginanthrin, Coeloginanthrid in dan Combretastatin C-1. Struktur kimia seperti terdapat pada Gambar 7. Bagian organ yang dimanfaatkan adalah pseudobulbus. Gum pada pseudobulbus dioleskan pada tempat yang sakit (Chauhan, 1999; Das \& Bhattacherjee, 2006). Pemanfaatan jenis Coelogyne yang lain untuk bahan obat herbal antara lain: Coelogyne corymbosa Lindl. Bagian organ dimanfaatkan adalah pseudobulbus. Jus pseudobulbus yang segar digunakan untuk penyembuhan luka bakar (Jana et al., 1997; Kumar, 2002).

Pada organ pseudobulbus anggrek Coelogyne fuscescens Lindl. dapat dibuat dalam pasta untuk obat sakit perut (Kumar, 2002). Pseudobulbus dari Coelogyne punctulata Lindl. dapat dirubah menjadi bentuk tepung yang digunakan untuk penyembuhan luka dan luka bakar (Singh, 2001).

Jenis anggrek Coelogyne nervosa A. Rich. merupakan tumbuhan endemik India Selatan yang dimanfaatkan sebagai obat herbal. Anggrek ini umumnya ditemukan tumbuh pada cabang pohon di Kerala dan Tamil Nadu (Murugesan 2005). Anggrek $C$. nervosa terancam punah akibat dipanen secara berlebihan untuk perdagangan obat herbal. Penggunaan anggrek ini sebagai obat tradisional, tumbuhan anggrek yang telah dewasa dikumpulkan dalam skala besar dan secara komersial diperdagangkan pada pasar lokal tanpa usaha pembudidayaan (Murugesan $\&$ Balasubramanian, 2008). Bagian tanaman $C$. nervosa yang dieksplotasi sebagai tanaman obat antara lain akar, rhizoma, dan keseluruhan bagian tumbuhan. Beberapa anggrek yang mirip seperti $C$. nervosa yang mempunyai nilai therapeutic antara lain Cymbidium, Gastrodia, 


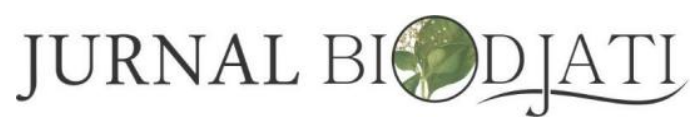

http://journal.uinsgd.ac.id/index.php/biodjati

Habenaria dan Vanda) telah dibudidayakan melalui kultur in vitro (Sharma et al., 2007; Kaur \& Bhutani, 2009; Giri et al., 2012).

Anggrek spesies Phalaenopsis manii terdapat di Kalimantan Tengah. Menurut Bulpitt et al. (2007), P. mannii Rchb. f., Phalaenopsis equestris (Schauer) Rchb. f., Phalaenopsis ambilis (L.). Blume mengandung phalaenopsine dengan struktur kimia seperti pada Gambar 8. Namun demikian belum dijelaskan pada literatur mengenai manfaat phalaenopsine. Potensi pseudobulbus pada jenis Bulbophyllum sebagai minuman yang menyehatkan. Roy et al. (2007), dan Hossain (2009) menjelaskan bahwa pseudobulbus pada Bulbophyllum lilacinum Ridl. dapat digunakan sebagai obat herbal. Cairan dari pseudobulbus yang telah dibersihkan kemudian disimpan dalam stoples yang rapat selama semalam kemudian dicampur dengan air sebagai minuman dingin. Minuman tersebut untuk menghilangkan kelelahan, kegelisahan dan membuat tubuh bugar serta segar. Bagian organ pseudubulbus dari Bulbophyllum neilgherrense yang dibuat ekstrak jus digunakan untuk pemulihan stamina, peremajaan dan sebagai tonik. Genus Bulbophyllum yang ditemukan di Kalimantan Tengah antara lain Bulbophyllum reticulatum, B. beccarii, B. lepidum, dan B. flavescens. Jenis-jenis Bulbophyllum tersebut belum dimanfaatkan oleh masyarakat dan belum ditemukan literatur mengenai manfaat sebagai bahan obat herbal, namun mempunyai potensi sebagai tanaman hias karena mempunyai bunga yang indah dan unik.

Berdasar hasil penelitian tersebut di atas maka disimpulkan bahwa anggrek spesies dari Kalimantan Tengah mempunyai potensi sebagai bahan obat herbal dengan manfaat dan bagian organ yang digunakan berbeda-beda antar spesies. Organ batang dan daun anggrek tewu tadung/anggrek tebu (G. speciosum) sebagai bahan obat kista. Akar uwei menyame (B. finlaysoniana (Lind.) Miq.) sebagai salah satu komponen obat sakit pinggang. Beberapa anggrek spesies yang berpotensi sebagai bahan obat herbal dan fitoterapi berdasar studi literatur antara lain: rhizoma anggrek bambu (Arundina graminifolia (D. Don) Hochr) mengandung senyawa Arundinan mempunyai aktivitas anti bakteri. Daun Phalaenopsis manii mengandung phalaenopsine. Seluruh bagian tumbuhan Eria bambusifolia Lindl. Kimar digunakan untuk mengatasi keasaman lambung yang berlebihan dan gangguan sakit perut. Anggrek Coelogyne cristata mengandung Coeloginanthrin, Coeloginanthrid in, dan Combretastatin C-1. Daun anggrek merpati Dendrobium crumenatum Sw. Dapat digunakan untuk tapal pada bisul dan jerawat. Pseudobulbus dari genus Bulbophyllum mempunyai potensi sebagai bahan minuman yang menyegarkan untuk pemulihan stamina, peremajaan dan sebagai tonik. Anggrek spesies Kalimantan Tengah genus Bulbophyllum belum dimanfaatkan sebagai obat herbal dan hingga saat ini hanya beberapa jenis yang dimanfaatkan sebagai tanaman hias karena berbunga indah.

\section{UCAPAN TERIMA KASIH}

Terimakasih kepada Ibu Setya Murniasih pemilik koleksi dan budidaya anggrek spesies Kalimantan Tengah di Jl. Temanggung Tilung XIII Palangka Raya yang telah memberi informasi dan kegigihan beliau dalam upaya budidaya dan konservasi ex-situ anggrek spesies Kalimantan Tengah.

\section{DAFTAR PUSTAKA}

Ariati, (2015). Jenis Tumbuhan Berkhasiat Obat di Kelurahan Muara, Tuhup Kabupaten Murung Raya, Kalimantan 


\section{JURNAL BIDDJATI}

http://journal.uinsgd.ac.id/index.php/biodjati

Tengah. Skripsi. Program Studi Pendidikan Biologi, Jurusan Pendidikan MIPA FKIP Universitas Palangka Raya.

Auberon F., Olatunji O. J., Krisa S., Antheaume C., Herbette G., Bonté F, Mérillon J. M \& Lobstein A. (2016). Two New Stilbenoids from the Aerial Parts of Arundina graminifolia (Orchidaceae). Molecules 21(11): 1430.

Bhattacharjee S. K. (2006). Herbaceous Perenials and Shade Loving Foliage Plants. Jaipur, India. Pointer Publishers.

Brummitt, N. (2013). Redlist of Threatened Species IUCN.

Bulpitt, C. J., Li, Y., Bulpitt, P. F. \& Wang, J. J. R. (2007). Soc Med; 100:558-63. Slaytor MB. In: Arditti J, editor. Orchid biology: reviews and perspectives. Ithaca: Cornell University Press; 1977. p. 95-115.

Chan C. L., A. Lamb, P. S. Shim \& Wood, J. J. (1994). Orchids of Borneo. Vol. Introduction and Selection of Species. The Sabah Society, Kota Kinibalu.

Chauhan, N.S. (1999). Medicinal and aromatic plants of Himachal Pradesh. New Dehli, India: Indus Publishing Company..

Chen T. H., Pan S. L., Guh J. H., Liao C.H., Huang, D. Y., Chen C. C \& Teng C.M. (2008). Moscatilin induces apoptosis in human colorectal cancer cells: a crucial role of c-Jun NH2-terminal protein kinase activation caused by tubulin depolymerization and DNA damage. Clin Cancer Res, 14:4250.

Das S. P. \& Bhattacherjee S. K. (2006). Orchids. In: Bhattacherjee S.K., editor. Herbaceous perennials and shade loving foliage plants. Jaipur, India: Pointer Publishers.

Dressler, R. L. (1993). Phylogeny and classification of the orchid family. USA:

Cambridge University Press;
Giri L., P. Dhyani., S. Rawat, Bhatt, I. D., Nandi S.K., Rawal R.S \& Pande V. (2012). In vitro production of phenolic compounds and antioxidant activity in callus suspension cultures of Habenaria edgeworthii: a rare Himalayan medicinal orchid. Industrial Crops and Products 39: 1-6.

Ho, C. K. \& Chen, C. C. (2003). Moscatilin from the orchid Dendrobrium loddigesii is a potential anticancer agent. Cancer Investig 21:729-36

Honda, C. \& Yamaki, M. (2000). Phenanthrenes from Dendrobium plicatile. Phytochemistry : 53(8):987-990.

Hossain, M. M. (2009). Traditional therapeutic uses of some indigenous orchids of Bangladesh. Medicinal and Aromatic Plant Science and Biotechnology. 2009; 42(1):101-106.

Hossain, M. M. (2011). Therapeutic Orchids: Traditional Uses and Recent Advances-An Overview. Fitoterapia 82: 102-140.

Jana, S. K., Sinha, G. P. \& Chauhan, A.S. (1997). Ethnobotanical aspects of orchids of shikim. The Journal of the Orchid Society India 11:79-84.

Kaur, S. \& Bhutani, K. K. (2009). In vitro propagation of Vanda testacea (Lindl.) Reichb.f. e a rare orchid of high medicinal value. Plant Tissue Culture and Biotechnology, 19: 1e7.

Kumar, S. (2002). The medicinal plants of North-East India. Judhpur, India: Scientific Publishers.

Li, Y., Wang, C. L., Guo, S. X., Yang, J. S. \& Xiao, P. G. (2008). Two new compounds from Dendrobium candidum. Chemical and Pharmaceutical Bulletin :56(10):1477-1479.

Liu, M. F.; Ding, Y. \& Zhang, D.M. (2005). Phenanthrene constituents from rhizome 


\section{JURNAL BIDDJATI}

http://journal.uinsgd.ac.id/index.php/biodjati

of Arundina graminifolia. Zhongguo Zhong Yao Za Zhi 30: 353-356.

Lo, S. F., Mulabagal, V., Chen, C. L., Kuo, C. L. \& Tsay, H. S. (2004). Bioguided fractionation and isolation of free radical scavenging components from in vitro propagated Chinese medicinal plants Dendrobium tosaense makino and Dendrobium moniliforme SW. J. Agr. Food Chem.52:6916-6919.

Krohn K., Loock U., Paavilainen K., Hausen B.M., Schmalle H.W. \& Kiesele H. (2001). Synthesis and electrochemistry of annoquinone-A, cypripedin methyl ether, denbinobin and related 1, phenanthrenequinones. Arkivoc 1(1):88130.

Majumder, P. L. \& Sen R. C. (1987). Moscatilin, a bibenzyl derivative from the orchid Dendrobium moscatum. Phytochemistry. ;26(7):2121-2124.

Majumder, P. L. \& Chatterjee, S. (1989). Crepidatin, a bibenzyl derivative from the orchid Dendrobium crepidatum. Phytochemistry. ;28(7):1986-1988.

Majumder, P. L. \& Pal (Née Ray) S. (1992). Rotundatin, a new 9, 10 didydrophenanthrene derivative from Dendrobium rotundatum. Phytochemtry: 31 (9) : 3225-3228.

Majumder. P. L., Sen, S. \& Majumber, S. (2001). Phenanthrene derivatives from the orchid Coelogyne cristata. Phytochemistry : 58(4): 581-586

Murugesan, M. (2005). Floristic diversity and ethnobotanical studies in Velliangiri Hills, the Western Ghats of Coimbatore district, Tamil Nadu, India. PhD thesis. Bharathiar University, Coimbatore, Tamil Nadu, India.

Murugesan, M. \& Balasubramanian, V. (2008). A survey on the orchids of Velliangiri Hills, a part of Nilgiri biosphere reserve, India, with special reference to Indian endemics. Journal of Scientific Transactions and Environmental Technovation 1: 186-200.

Roy, A. R., Patel, R. S., Patel, V. V \& Yadav, D. S. (2007). Medicinal orchids of Meghalaya. The Journal of Orchid Society of India 21:15-7.

Sabran, M., Krismawati, A, Galingging, Y. R \& Firmansyah, A. M. (2003). Eksplorasi dan Karakterisasi Tanaman Anggrek di Kalimantan Tengah. Buletin Plasma Nutfah Vol.9 No.1.

Sharma, V. K., Hansch, R., Mendel, R. R \& Schulze, J. (2007). Node-derived cultures with high-morphogenic competence in barley and wheat. Plant Cell Tissue and Organ Culture 88: 21e33.

Singh, DK. In: Pathak, P, Sehgal, R. N, Shekhar N, Sharma, M. \& Sood, A. (2001). Orchids: science and commerce, New Delhi. p. 35.

Singh, A. \& Duggal, S. (2009). Medicinal orchids: An overview. Ethnobotanical leaflets. 13:351-63.

Zhang, X., Xu, J. K \& Wang, J. (2007). Bioactive bibenzyl derivatives and fluorenones from Dendrobium nobile . Jou rnal of Natural Products. 70 (1):24-28. 